\title{
Ocena rządowego projektu ustawy o ochronie danych osobowych przetwarzanych w związku z zapobieganiem i zwalczaniem przestępczości (druk sejmowy nr 2989) w świetle dyrektywy Parlamentu Europejskiego i Rady (UE) 2016/680 ${ }^{1}$
}

Assessment of the governmental Bill on the Protection of Personal Data Processed in Relation to the Prevention of and Fighting Crime (Sejm's Paper no. 2989) in the light of the Directive of the European Parliament and of the Council (EU) 2016/680: The bill does not contain proposals of provisions extending the subject of the act implementing the European Union law or beyond the framework of the Directive 2016/680. The bill includes proposals for provisions that may be considered incompatible with the European Union law or that incompletely implement acts of this law. In this regard, it would be required to improve the bill during further legislative proceedings.

Keywords: personal data protection, bill, crime/delinquency, European Union Słowa kluczowe: ochrona danych osobowych, projekt ustawy, przestępczość, Unia Europejska

\section{Przedmiot opinii}

Przedmiotem opinii jest ocena rządowego projektu ustawy o ochronie danych osobowych przetwarzanych $\mathrm{w}$ związku z zapobieganiem i zwalczaniem prze-

1 Opinia prawna dotyczaca zakresu rzadowego projektu ustawy o ochronie danych osobowych przetwarzanych $w$ zwiazku z zapobieganiem i zwalczaniem przestępczości (druk nr 2989) w świetle dyrektywy Parlamentu Europejskiego i Rady (UE) 2016/680 sporządzona 28 listopada 2018 r. na zlecenie przewodniczącego Komisji Cyfryzacji, Innowacyjności i Nowoczesnych Technologii; BAS-WAPM 2765/18. 
stępczości (dalej: projekt ustawy), pod kątem właściwego wprowadzenia prawa UE. Chodzi o odpowiedź na pytanie: „na ile projekt ustawy wykracza poza ramy określone w dyrektywie Parlamentu Europejskiego i Rady (UE) 2016/680 z 27 kwietnia 2016 r. w sprawie ochrony osób fizycznych w związku z przetwarzaniem danych osobowych przez właściwe organy do celów zapobiegania przestępczości, prowadzenia postępowań przygotowawczych, wykrywania i ścigania czynów zabronionych i wykonywania kar, w sprawie swobodnego przepływu takich danych oraz uchylającej decyzję ramową Rady 2008/977/WSiSW"3; (dalej: dyrektywa 2016/680).

Problem dotyczący tego, na ile projekt ustawy wykracza poza ramy określone w dyrektywie, może być rozumiany dwojako. Po pierwsze, w przypadku projektu ustawy wykonującej prawo Unii Europejskiej powstaje kwestia, w jakim zakresie taki projekt może zawierać propozycje przepisów niemających na celu wykonania prawa UE. Po drugie, z perspektywy prawidłowego wdrożenia dyrektywy istotne jest to, czy krajowy prawodawca nie wprowadza dodatkowych (ponad standard wyznaczony dyrektywą) regulacji, których efektem jest utrudnienie osiągnięcia celu wyznaczonego przez unijnego prawodawcę.

Poniżej zostaną przedstawione uwagi odnoszące się do obu wskazanych obszarów, także dodatkowe spostrzeżenia w zakresie poprawności propozycji zawartych w projekcie ustawy w świetle dyrektywy 2016/680. Należy jednak zastrzec, że niniejsza opinia nie zawiera kompleksowej oceny zgodności projektu ustawy z prawem UE.

\section{Zakres projektu ustawy wykonującej prawo UE}

W opiniowanym projekcie ustawy zawarto stwierdzenie, że ma on na celu wykonanie prawa Unii Europejskiej. W postępowaniu ustawodawczym w odniesieniu do projektów ustaw wykonujących prawo UE przewiduje się szczególne regulacje proceduralne, które na gruncie regulaminu Sejmu wiążą się przede wszystkim z ustaleniem kalendarza prac w Sejmie nad takim projektem (art. 95b regulaminu Sejmu) oraz wymogiem zgłaszania poprawek na posiedzeniu komisji przez grupę co najmniej 3 posłów, w formie pisemnej (art. 95d ust. 1 regulaminu Sejmu). W związku z tym niebagatelne znaczenie ma to, aby w projektach ustaw wykonujących prawo UE nie zamieszczać dodatkowych materii niezwiązanych z głównym przedmiotem regulacji. W przeciwnym razie zostaje wypaczona ratio legis proceduralnego zróżnicowania rozpatrywania „zwykłych” projektów ustaw oraz projektów ustaw wykonujących prawo UE.

\footnotetext{
Druk sejmowy nr 2989/VIII kad.

3 Dz.Urz. UE L 119 z 4 maja 2016 r., s. 89.
} 
Dodatkowo należy odnotować, że uwzględniając racjonalność działania ustawodawcy oraz zasady prawidłowej legislacji, dopuszczalne jest zawarcie w projekcie ustawy wykonującej prawo UE pewnych materii niewynikających bezpośrednio z treści aktów prawa unijnego. W szczególności w sytuacji przedkładania projektów nowych ustaw mających na celu wdrożenie do polskiego porządku prawnego dyrektyw konieczne bywa zaproponowanie przepisów, które są wymagane np. na podstawie Zasad techniki prawodawczej ${ }^{4}$, a nie można ich wprost przypisać do konkretnych postanowień wdrażanej dyrektywy.

Jeśli chodzi o rządowe projekty ustaw, trzeba wskazać, że $₫ 30$ ust. 2 Regulaminu pracy Rady Ministrów ${ }^{5}$ stanowi: Projekt ustawy mającej na celu wdrożenie prawa Unii Europejskiej może zawierać przepisy wykraczające poza ten cel wyłacznie $w$ szczególnie uzasadnionych przypadkach. W takim przypadku organ wnioskujący dołacza do projektu dodatkowo tabelaryczne zestawienie projektowanych przepisów ustawy, które wykraczaja poza cel wdrożenia prawa Unii Europejskiej, wraz z wyjaśnieniem niezbędności objęcia ich tym projektem, zwane dalej „odwrócona tabela zgodności".

Odwrócona tabela zgodności jest zatem podstawowym instrumentem, który pozwala ocenić, jak duży zakres przedłożonego projektu ustawy stanowią przepisy, które nie mają na celu wykonania prawa UE. Do opiniowanego projektu ustawy taka odwrócona tabela zgodności została dołączona. Odnośnie do zawartej w niej treści należy wszakże zgłosić zastrzeżenie. A mianowicie w przypadku 14 na 38 wymienionych w niej przepisów (poz. 18-31 w tabeli) jako uzasadnienie wprowadzenia przepisu podano konieczność dostosowania danej nowelizowanej ustawy do rozwiązań wprowadzonych przez rozporządzenie Parlamentu Europejskiego i Rady (UE) nr 2016/679 z 27 kwietnia 2016 r. w sprawie ochrony osób fizycznych w związku z przetwarzaniem danych osobowych i w sprawie swobodnego przepływu takich danych oraz uchylenia dyrektywy 95/46/WE (ogólne rozporządzenie o ochronie danych)'; (dalej: rozporządzenie RODO). Nawet przy uwzględnieniu tego, że wskazane przepisy służą stosowaniu unijnego rozporządzenia, a nie wdrożeniu dyrektywy, należałoby umieścić je nie w odwróconej tabeli zgodności, lecz w tabeli zgodności dołączonej do projektu ustawy. Wprawdzie zgodnie $\mathrm{z} \$ 30$ ust. 1 Regulaminu pracy Rady Ministrów do projektu ustawy mającej na celu wdrożenie prawa UE dołącza się: tabelaryczne zestawienie przepisów dyrektywy lub dyrektyw, których wdrożenie jest celem projektu, oraz projektowanych przepisów prawa polskiego, czyli tzw. tabelę zgodności, to w praktyce stosowania tego postanowienia przyjęło się w ta-

4 Rozporządzenie Prezesa Rady Ministrów z 20 czerwca 2002 r. w sprawie „Zasad techniki prawodawczej”, t.j. Dz.U. 2016, poz. 283.

5 Uchwała nr 190 Rady Ministrów z 29 października 2013 r. - Regulamin pracy Rady Ministrów, M.P. 2016, poz. 1006, ze zm.

6 Dz.Urz. UE L 119 z 27 kwietnia 2016 r., s. 1. 
belach tego rodzaju zamieszczać także przepisy mające związek z wykonaniem rozporządzeń UE?

Biorąc powyższe pod uwagę, należy odnotować, że zamieszczone w odwróconej tabeli zgodności przepisy ustawy, które wykraczają poza cel wdrożenia prawa Unii Europejskiej, obejmują 24 jednostki redakcyjne (całe artykuły lub ich części), natomiast projekt ustawy liczy 109 artykułów (w tym 42 artykuły zawierające obszerne nowelizacje innych ustaw). W konsekwencji trzeba stwierdzić, że przedmiot opiniowanej ustawy nie wykracza poza przyjęte w praktyce ustawodawczej określenie przedmiotu ustawy wykonującej prawo Unii Europejskiej.

\section{Wykroczenie poza wymogi dyrektywy}

Zgodnie z art. 288 Traktatu o funkcjonowaniu Unii Europejskiej (TFUE) dyrektywa wiąże każde państwo członkowskie, do którego jest kierowana, w odniesieniu do rezultatu, który ma być osiągnięty, pozostawia jednak organom krajowym swobodę wyboru formy i środków. Wynika z tego, że dyrektywa jest aktem prawa pochodnego, który pozwala krajowemu prawodawcy na daleko idącą swobodę w zakresie legislacyjnego sposobu wdrożenia. Nie oznacza to jednak pełnej dowolności, gdyż działania prawodawcze w państwie członkowskim nie mogą prowadzić do sytuacji, w której formalne wykonanie obowiązku wdrożenia dyrektywy zostaje $\mathrm{w}$ praktyce zniweczone $\mathrm{z}$ powodu nieprawidłowego przeniesienia regulacji unijnej na grunt krajowy. Podstawowym instrumentem prawnym, który służy kontroli prawidłowego wdrażania dyrektyw, jest skarga Komisji Europejskiej do Trybunału Sprawiedliwości UE, dotycząca naruszenia traktatów przez państwo członkowskie, o której mowa w art. 258 TFUE.

W związku z pytaniem sformułowanym na początku opinii, dotyczącym wykroczenia projektu ustawy poza ramy określone w dyrektywie 2016/680, należy zwrócić uwagę na problem nadmiernego wdrożenia (nadmiernej transpozycji) prawa UE, często określanego anglojęzycznym terminem gold-plating ${ }^{8}$. Takie działanie państwa członkowskiego, które polega na wprowadzaniu dodatkowych wymogów lub obciążeń biurokratycznych, zaciemnia cele wyznaczone w dyrektywie i może utrudnić ich realizację ${ }^{9}$ Komisja Europejska w komunikacie pt.

7 Zob. rządowy projekt ustawy o ochronie danych osobowych, druk sejmowy nr 2410/ VIII kad.

8 Zob. np. Research for REGI Committee - Gold-plating in the European Structural and Investment Funds, http://www.europarl.europa.eu/RegData/etudes/STUD/2017/585 906/IPOL_STU(2017)585906_EN.pdf.

9 Zob. opinia Europejskiego Komitetu Ekonomiczno-Społecznego w sprawie sposobów wdrażania i egzekwowania prawodawstwa UE, Dz.Urz. UE C 24 z 31 stycznia 2006 r., s. 13. 
„Program UE - Lepsze wyniki dzięki lepszemu stanowieniu prawa” stwierdziła, że: państwa członkowskie podczas wdrażania prawodawstwa UE na poziomie krajowym często wykraczaja poza jego ścisłe wymogi, tzn. nadmiernie rygorystycznie wdrażaja przepisy UE. Może to zwiększać korzyści, ale może również powodować niepotrzebne koszty dla przedsiębiorstw i organów publicznych, które sa wtedy mylnie przypisywane prawodawstwu UE ${ }^{10}$. W orzecznictwie TSUE wskazuje się m.in. na to, że rozszerzanie zakresu stosowania danej dyrektywy lub wybór szerszego użycia dopuszczonego w niej swobodnego uznania nie pozostaje bez wpływu na zakres stosowania prawa UE w państwie członkowskim ${ }^{11}$.

Trzeba podkreślić, że dokonanie oceny, czy w danym wypadku mamy do czynienia z nadmiernym wdrożeniem dyrektywy, musi uwzględniać to, czy dyrektywa zmierza do minimalnej harmonizacji (co daje zazwyczaj większe pole działania państwu członkowskiemu), czy do pełnej harmonizacji (co w istotny sposób ogranicza możliwości prawotwórcze państwa członkowskiego). Ponadto nie zawsze łatwo jest rozgraniczyć to, co stanowi nadmierną regulację od sytuacji, w której przepis prawa krajowego po prostu narusza postanowienia dyrektywy. Analiza pod tym kątem wdrożenia całej dyrektywy wymaga zatem kompleksowego porównania jej poszczególnych postanowień oraz wdrażających je przepisów prawa krajowego.

Odnośnie do opiniowanego projektu ustawy należy wskazać, że wdrażana na jego mocy dyrektywa 2016/680 stanowi w art. 1 ust. 3, iż dyrektywa ta nie wyklucza ustanowienia przez państwa członkowskie zabezpieczeń wyższych niż zabezpieczenia przewidziane w niej dla ochrony praw i wolności osoby, której dane dotyczą, w związku z przetwarzaniem danych osobowych przez właściwe organy. W tym zakresie wprost dopuszczono zatem możliwość wykroczenia przez ustawodawcę krajowego ponad standard ustalony w dyrektywie 2016/680. W dołączonej do projektu ustawy tabeli zgodności w rubryce dotyczącej uzasadnienia uwzględnienia w projekcie przepisów wykraczających poza minimalne wymogi prawa UE nie wskazano żadnego przepisu, który mógłby mieć taki charakter.

Analiza projektu ustawy, uwzględniająca powyższe przesłanki, pozwala przyjąć, że nie zawiera on propozycji przepisów, które wykraczałyby poza ramy wyznaczone w dyrektywie 2016/680. Jednocześnie należy zastrzec, że krótki termin na sporządzenie opinii na temat obszernego projektu ustawy nie pozwolił na dokonanie jego bardziej wnikliwej oceny.

10 Komunikat Komisji do Parlamentu Europejskiego, Rady, Europejskiego Komitetu Ekonomiczno-Społecznego i Komitetu Regionów z 19 maja 2015 r., COM(2015) 215 final. Zob. także komunikat Komisji do Parlamentu Europejskiego, Rady Europejskiej i Rady z 14 września 2016 r.: „Lepsze stanowienie prawa: silniejsza Unia dzięki lepszym wynikom”, COM(2016) 615 final.

11 Zob. wyrok TSUE z 17 października 2013 r. w sprawie C-184/12, Unamar, pkt 50. 


\section{Uwagi na temat zgodności niektórych przepisów projektu ustawy $z$ prawem UE}

W załączonej do opiniowanego projektu ustawy opinii Ministra Spraw Zagranicznych o zgodności tego projektu z prawem Unii Europejskiej podniesiono zarzuty niezgodności art. 3 pkt 1 projektu ustawy z art. 2 ust. 2 w związku z art. 3 pkt 6 dyrektywy 2016/680 oraz art. 3 pkt 2 projektu ustawy z art. 2 ust. 3 lit. a dyrektywy $2016 / 680^{12}$. Zarzuty te należy uznać za trafne, a $z$ uwagi na przedstawienie ich uzasadnienia we wskazanej opinii MSZ, niepotrzebne jest powtarzanie przywołanych tam argumentów.

W myśl art. 1 pkt 3 projektu ustawy ma ona określać sposób prowadzenia nadzoru nad ochroną danych osobowych przetwarzanych przez właściwe organy w celach, o których mowa w pkt 1, z wyłączeniem danych osobowych przetwarzanych przez prokuraturę i sądy. W ocenie skutków regulacji zawartej w uzasadnieniu do projektu ustawy wyłączenie z jej zakresu danych osobowych przetwarzanych przez prokuraturę uzasadniono, przywołując motyw 80 preambuły dyrektywy 2016/680. W motywie tym określono m.in., że: państwa członkowskie powinny mieć również możliwość przyjęcia, że właściwość organu nadzorczego nie obejmuje przetwarzania danych osobowych przez inne niezależne organy wymiaru sprawiedliwości $w$ toku sprawowania przez nie wymiaru sprawiedliwości, przykładowo przez prokuraturę. W świetle przytoczonego postanowienia wątpliwości budzi możliwość uznania prokuratury w rozumieniu polskiego prawa za „niezależny organ wymiaru sprawiedliwości” w rozumieniu dyrektywy 2016/680. W myśl art. 175 ust. 1 Konstytucji RP wymiar sprawiedliwości w Rzeczypospolitej Polskiej sprawują Sąd Najwyższy, sądy powszechne, sądy administracyjne oraz sądy wojskowe. Zgodnie z art. 2 ustawy z 28 stycznia 2016 r. - Prawo o prokuraturze (Dz.U. 2017, poz. 1767, ze zm.) prokuratura wykonuje zadania w zakresie ścigania przestępstw oraz stoi na straży praworządności, natomiast przymiot niezależności został $\mathrm{w}$ tej ustawie przypisany (w pewnym zakresie) prokuratorom $^{13}$, a nie prokuraturze. W konsekwencji należy stwierdzić, że art. 1 pkt 3 projektu ustawy w zakresie, w którym dotyczy prokuratury, może zostać uznany za niezgodny z dyrektywą 2016/680.

Dodatkowo warto rozważyć dodanie w odnośniku do tytułu projektowanej ustawy sformułowania, że służy ona stosowaniu rozporządzenia RODO. Taką klauzulę zamieszczono w przypisie nr 1 do tytułu ustawy z 10 maja 2018 r. o ochronie danych osobowych (Dz.U. poz. 1000, ze zm.). Zamieszczenie takiej informacji nie wynika wprawdzie wprost z rozporządzenia RODO, jednak byłoby to korzystne z punktu widzenia adresata ustawy, który może nie być świadomy

12 Opinia MSZ załączona do druku sejmowego nr 2989/VIII kad.

13 Art. $7 \$ 1$ : Prokurator przy wykonywaniu czynności określonych $w$ ustawach jest niezależny, z zastrzeżeniem $\$ 2-6$ oraz art. 8 i art. 9. 
tego, że projektowana ustawa nie tylko wdraża dyrektywę 2016/680, ale zawiera również przepisy nowelizujące inne ustawy w celu dostosowania do wymogów rozporządzenia RODO (zob. uwagi nt. odwróconej tabeli zgodności).

Artykuł 8 ust. 3 projektu ustawy stanowi: 3. Decyzje Prezesa Urzędu [Ochrony Danych Osobowych], o których mowa w ust. 1 [powinno być - ust. 2, dopisek T.J.], nie moga nakazywać usunięcia danych osobowych zebranych $w$ toku czynności operacyjno-rozpoznawczych prowadzonych na podstawie przepisów prawa. Administrator w przypadku uznania, że zgromadzone w ten sposób dane są zbędne, jest zobowiązany do ich usunięcia. W przypadku niedopetnienia obowiązku usunięcia danych osobowych przez administratora Prezes Urzędu może nakazać ich usunięcie. W celu realizacji uprawnienia Prezes Urzędu nie uzyskuje dostępu do danych osobowych, o których mowa $w$ zdaniu pierwszym. Administrator lub podmiot przetwarzajacy dane osobowe, o których mowa w zdaniu pierwszym, jest zobowiazany do niezwłocznego przywrócenia zgodnego $z$ prawem sposobu ich przetwarzania. Przywołana regulacja może zostać uznana za niezgodną z art. 47 ust. 2 lit. b dyrektywy 2016/680, zgodnie z którym państwa członkowskie zapewniają, by każdy organ nadzorczy posiadał skuteczne uprawnienia naprawcze, przykładowo takie jak nakazanie administratorowi lub podmiotowi przetwarzającemu dostosowania operacji do przepisów przyjętych na podstawie tej dyrektywy, w razie potrzeby w konkretny sposób i w konkretnym terminie, zwłaszcza poprzez nakazanie sprostowania lub usunięcia danych osobowych lub ograniczenia ich przetwarzania zgodnie z art. 16 dyrektywy 2016/680. Konstatacja, że można ograniczyć zakres danych osobowych, których usunięcie nakazuje Prezes Urzędu (gdyż w art. 47 ust. 2 lit. b dyrektywy 2016/680 jest mowa o usunięciu danych osobowych lub ograniczeniu ich przetwarzania), nie jest tutaj wystarczająca, ponieważ konstrukcja art. 8 ust. 3 projektu ustawy w daleko idącym stopniu utrudnia temu organowi ocenę tego, w stosunku do jakich danych osobowych powinno być wprowadzone ograniczenie przetwarzania.

W art. 49 ust. 3 projektu ustawy, który ma na celu wdrożenie art. 50 dyrektywy 2016/680, należy skorygować błędne sformułowanie, że Prezes Urzędu może wykorzystywać ,informacje otrzymane od innego państwa członkowskiego w innych państwach Unii Europejskiej” wyłącznie w celu określonym we wniosku o pomoc. W przepisie tym powinno chodzić o ,informacje od organów nadzorczych w innych państwach Unii Europejskiej”.

\section{Podsumowanie}

- Projekt ustawy nie zawiera propozycji przepisów wykraczających poza przedmiot ustawy wykonującej prawo Unii Europejskiej.

- Projekt ustawy nie zawiera propozycji przepisów wykraczających poza ramy wyznaczone w dyrektywie 2016/680. 
- W projekcie ustawy znajdują się propozycje przepisów, które mogą zostać uznane za niezgodne z prawem Unii Europejskiej lub w niepełnym stopniu wdrażające akty tego prawa. W tym zakresie wymagane byłoby poprawienie projektu ustawy w trakcie dalszych prac legislacyjnych. 